\title{
Projekt budżetu ogólnego Unii Europejskiej na rok budżetowy 2019 - Ogólne wprowadzenie - Ogólne zestawienie dochodów - Zestawienie dochodów i wydatków w podziale na sekcje ${ }^{1}$
}

\begin{abstract}
Draft General Budget of the European Union for the financial year 2019 - General introduction - General statement of revenue - Statement of revenue and expenditure by section (WASiE/WAPM-1832/18): The opinion presents the most important assumptions of the Draft General Budget of the EU for the fiscal year 2019. The document contains description of priorities adopted during drafting, planned revenues, expenditures, and changes over time (compared to the previous budget) in the projected amounts. The Polish government's position on the 2019 Draft General Budget is positively assessed, including the government's statement that during the work on the budget it will be striving for provision of the financial resources necessary to repay the liabilities contracted earlier by the Member States on behalf of the EU budget (it is particularly related to cohesion policy and development of rural areas - both being very important investment instruments in the EU).
\end{abstract}

Keywords: budget, European Union

Słowa kluczowe: budżet, Unia Europejska

* Doktor nauk ekonomicznych, naczelnik Wydziału Analiz Społecznych

i Ekonomicznych BAS; zofia.szpringer@sejm.gov.pl.

* Doktor nauk prawnych, adiunkt w Katedrze Prawa Administracyjnego i Samorządu Terytorialnego WPiA UKSW; naczelnik Wydziału Analiz Prawa Europejskiego i Międzynarodowego BAS; ziemowit.cieslik@sejm.gov.pl.

$1 \quad$ Opinia w sprawie projektu budżetu ogólnego Unii Europejskiej na rok budżetowy 2019 Ogólne wprowadzenie - Ogólne zestawienie dochodów - Zestawienie dochodów i wydatków w podziale na sekcje sporządzona 16 lipca 2018 r. na zlecenie przewodniczącej Komisji do Spraw Unii Europejskiej; BAS-WASiE/WAPM 1832/18. 


\section{Opinia merytoryczna}

\section{Przedmiot dokumentu UE}

\section{- Treść dokumentu UE}

Zaproponowany projekt budżetu ogólnego na rok $2019^{2}$ będzie szóstym, a zarazem przedostatnim budżetem $w$ ramach obecnych wieloletnich ram finansowych (WRF) dotyczących lat 2014-2020. Będzie on wykonywany w roku wyborów do Parlamentu Europejskiego oraz w czasie wychodzenia z Unii Europejskiej Zjednoczonego Królestwa, co nie oznacza jednak, że kraj ten nie będzie partycypował w tym i kolejnym jeszcze budżecie ${ }^{3}$.

Komisji Europejskiej zależy na terminowym przyjęciu budżetu, po to by zapewnić stabilność, przewidywalność i ciągłość warunków obecnej ścieżki dochodzenia UE do zrównoważonego wzrostu i spójności gospodarczej.

Dlatego też w tym budżecie nadal będzie wspieranych dziesięć priorytetów politycznych wskazanych przez przewodniczącego Komisji Europejskiej C. Junckera na początku jego kadencji, z położeniem nacisku na inwestowanie w silniejszą i odporniejszą gospodarkę europejską oraz na promowanie solidarności i bezpieczeństwa po obu stronach unijnych granic ${ }^{4}$. Ponadto uwzględnione zostały wytyczne Rady i Parlamentu przyjęte w dniach 20 lutego i 9 marca 2018 r. ${ }^{5}$.

Http://eur-lex.europa.eu/budget/www/index-pl.htm.

3 Zgodnie z art. 50 Traktatu o Unii Europejskiej Zjednoczone Królestwo powiadomiło o swoim zamiarze wystąpienia z UE z dniem 30 marca 2019 r. Niemniej na potrzeby projektu budżetu na 2019 r. Zjednoczone Królestwo traktowane jest jak państwo członkowskie. W pkt 59 wspólnego sprawozdania negocjatorów UE i rządu Zjednoczonego Królestwa oraz komunikatu Komisji do Rady Europejskiej (COM(2017)784 final, 8 grudnia 2017 r.) stwierdzono, że Zjednoczone Królestwo wnosi wkład do budżetów rocznych Unii na lata 2019 i 2020 oraz uczestniczy w ich wykonaniu, jak gdyby nadal było członkiem Unii.

$4 \quad$ W tym też aspekcie podkreślono znaczenie Europejskiego Funduszu na rzecz Inwestycji Strategicznych (EFIS). Wskazano bowiem, że EFIS, który był utworzony w 2015 r., do kwietnia 2018 r. osiągnął 90\% swojego pierwotnego celu, jakim jest uruchomienie 315 mld euro na potrzeby inwestycji infrastrukturalnych i innowacji. We wszystkich państwach UE podpisane zostały umowy finansowe i oczekuje się, że 611 tys. małych i średnich przedsiębiorstw będzie miało dostęp do finansowania pozyskanego dzięki gwarancjom publicznym zapewnionym przez budżet UE. We wszystkich państwach członkowskich zwiększył się poziom inwestycji oraz tempo wzrostu, co proporcjonalnie przełożyło się na większą liczbę miejsc pracy. W 2017 r. wzrost w UE wynosił 2,4\% i był najwyższy w ciągu ostatnich 10 lat, a w marcu 2018 r. stopa bezrobocia osiągnęła $7,1 \%$, czyli poziom najniższy od 10 lat. Spadło również bezrobocie osób młodych: w 2013 r., kiedy było najwyższe, wynosiło 24\%, zaś w marcu 2018 r. - 15,6\%.

5 Konkluzje Rady w sprawie wytycznych budżetowych na 2019 r. (6315/18); rezolucja Parlamentu Europejskiego w sprawie ogólnych wytycznych dotyczących przygotowania budżetu na rok 2019 (2017/2286(BUD)). 
Budżet na rok 2019 w dalszym ciągu będzie oddziaływać na zwiększenie inwestycji i pobudzanie wzrostu gospodarczego, wspieranie zatrudnienia i tworzenie nowych miejsc pracy, wzmacnianie faktycznej spójności w UE i rolnictwa oraz wspieranie konkurencyjności. Jednocześnie uwzględniać będzie wymiar społeczny i środowiskowy, a w szczególności wspierać państwa członkowskie we wdrażaniu porozumienia paryskiego w wysiłkach na rzecz przeciwdziałania zmianom klimatu ${ }^{6}$. W budżecie przewidziano również nowe inicjatywy dotyczące wzrostu gospodarczego, który sprzyjać będzie włączeniu społecznemu, takie jak powołanie Europejskiego Urzędu ds. Pracy' nadal też położony zostanie nacisk na środki na rzecz młodzieży.

Budżet zapewni też środki na utworzenie Europejskiego Wspólnego Przedsięwzięcia w dziedzinie Obliczeń Wielkiej Skali poprzez m.in. wniesienie wkładu $\mathrm{z}$ instrumentu „Łącząc Europę”. Celem tego nowego podmiotu ma być promowanie najnowszych technologii obliczeń wielkiej skali oraz infrastruktury danych i wspieranie rozwoju technologii i jej zastosowania w wielu obszarach, $\mathrm{z}$ korzyścią dla naukowców, przemysłu i sektora publicznego ${ }^{8}$.

Poza tym w budżecie ujęto środki m.in. na potrzeby nowej Prokuratury Europejskiej, na Unijny Mechanizm Ochrony Ludności, na Europejski Program Rozwoju Przemysłu Obronnego, na Europejski Korpus Solidarności, na Instrument Pomocy dla Uchodźców w Turcji oraz na Program Wspierania Reform Strukturalnych 2.09.

Wieloletnie ramy finansowe, stanowiące pułap wydatkowy, zakładają na rok $2019^{10}$ :

- środki na płatności w kwocie 166,7 mld euro oraz

- środki na zobowiązania w wysokości 164,1 mld euro.

Przedłożony przez Komisję projekt budżetu UE na rok 2019 nieco odbiega od WRF, zakłada bowiem:

- dochody i środki na płatności w wysokości 148,7 mld euro ${ }^{11}$ oraz

6 Zgodnie z założeniem do 2020 r. 20\% budżetu ma być wykorzystane na przeciwdziałanie zmianom klimatu.

7 Https://ec.europa.eu/poland/news/europejski-urz\%C4\%85d-ds-pracy_pl.

8 Zob. COM(2018) 8 final.

9 Tabele obrazujące budżet ogólny UE na rok 2019 znajdują się w COM(2018) 600 final, s. 7, 208.

10 Dane liczbowe oparto na dostosowaniu technicznym ram finansowych na 2019 r. odpowiednio do zmian DNB, przyjętym przez Komisję w dniu 23 maja 2018 r., $\operatorname{COM}(2018) 282$ final.

11 Planowany poziom dochodów odpowiada poziomowi środków na płatności z uwagi na obowiązującą zasadę równowagi budżetu unijnego. 
- środki na zobowiązania (ang. commitment appropriations) w kwocie 165,6 mld euro.

Oznacza to, że środki na płatności będą poniżej limitu przyjętego w WRF o 18 mld euro, natomiast na zobowiązania niższe o 1,5 mld euro.

Niemniej na rok przyszły planuje się także wyższy margines środków na płatności (wyniesie 19,3 mld euro wobec ok. 11 mld euro w 2018 r.). Margines środków na zobowiązania będzie natomiast nieznacznie niższy (wyniesie 1,1 mld euro wobec 1,3 mld euro w 2018 r.).

Budżet ten uwzględnienia instrument elastyczności, na który zaplanowano więcej środków niż w 2018 r., jak również inne instrumenty szczególne obejmujące rezerwę na pomoc nadzwyczajną (EAR), Europejski Fundusz Dostosowania do Globalizacji (EFG) i Fundusz Solidarności Unii Europejskiej (FSUE), na które łącznie przewidziano mniej środków niż w roku $2018^{12}$.

Zaplanowane w budżecie środki na zobowiązania będą wyższe niż w roku 2018 o 4,9 mld euro (tj. 3,1\%), a środki na płatności wyższe o 3,9 mld euro (tj. o $2,7 \%)^{13}$. Nie są to wzrosty duże, niemniej w odniesieniu do płatności należy przypomnieć, że w uzasadnieniu projektu wskazuje się, iż opóźnienia $\mathrm{w}$ realizacji programów polityki spójności na lata 2014-2020 dawały powody do niepokoju w 2016 r. i przez większość 2017 r. Obecnie wydaje się, że trend ten odwrócił się, bowiem liczba składanych wniosków o płatności wzrosła gwałtownie w listopadzie i grudniu 2017 r., pojawiły się też oznaki, że nowe programy spójności wreszcie osiągnęły pełną zdolność operacyjną. Aby jednak uniknąć nagromadzenia zaległości w płatnościach na kolejne WRF, należy, zdaniem Komisji, zachować proaktywne podejście na wszystkich szczeblach. W tym względzie pomocna powinna się okazać uzgodniona w grudniu 2017 r. zmiana rozporządzenia finansowego; uproszczono przepisy, zwiększono przejrzystość oraz wprowadzono skuteczniejsze kontrole, po to aby środki publiczne były efektywniej wykorzystywane.

Komisja wskazuje również, że realizacja płatności w poprzednich WRF dobiega końca, a poziom płatności założony w budżecie na 2018 r. jest ambitny, dlatego też należy oczekiwać umiarkowanego wzrostu płatności w 2019 r. w porównaniu z $2018 \mathrm{r}$.

12 W ramach instrumentu elastyczności zaplanowano w 2019 r. w środkach na zobowiązania prawie 1 mld euro i w środkach na płatności 0,9 mld euro, tj. więcej niż w $2018 \mathrm{r}$. odpowiednio o 15,3\% i 32,6\%. Jednocześnie na inne instrumenty szczególne przewidziano na 2019 r. w środkach na zobowiązania prawie 0,6 mld euro i w środkach na płatności 0,4 mld euro, tj. mniej niż w 2018 r. odpowiednio o 13,1\% i 20,4\%.

13 Po uwzględnieniu korekt nr 1-3 dotyczących tegorocznego budżetu. Środki na zobowiązania stanowić będą w 2019 r. 1,0\% DNB, na płatności zaś 0,9\% DNB. 
Planowane zwiększenie dochodów budżetu unijnego o 3,9 mld euro wynikać będzie m.in. z istotnie wyższych wpłat z zasobów własnych opartych na dochodzie narodowym brutto - DNB (o 5,3 mld euro) oraz niższych wpłat z ceł i opłat wyrównawczych od cukru (o 1,4 mld euro). Towarzyszyć temu będzie zmniejszenie w takich m.in. niewielkich pozycjach jak: „nadwyżki, salda i dostosowania” oraz „dochody z działalności administracyjnej instytucji”.

W strukturze planowanych dochodów zasoby własne stanowić już będą 98,7\% dochodów ogółem, dochody zaś pochodzące od osób pracujących w instytucjach i innych organach UE - 1,1\%, natomiast wszystkie pozostałe dochody $0,2 \%$ (zob. tabela 1 ).

Tabela 1. Dochody w mln euro

\begin{tabular}{|c|c|c|c|c|c|c|}
\hline Poz. & Wyszczególnienie & $\begin{array}{c}\text { Budżet } \\
2018 *\end{array}$ & $\begin{array}{l}\text { Budżet } \\
2019\end{array}$ & $\begin{array}{l}\text { zmiana } \\
\text { proc. }\end{array}$ & $\begin{array}{c}\text { Struktura } \\
2018 \\
\text { w } \%\end{array}$ & $\begin{array}{l}\text { Struktura } \\
2019 \\
\text { w \% }\end{array}$ \\
\hline \multirow[t]{4}{*}{1} & Zasoby własne & 142374,4 & 146771,6 & 3,1 & 98,3 & 98,7 \\
\hline & $\begin{array}{l}\text { - kwota netto ceł i opłat wyrównawczych } \\
\text { od cukru }\end{array}$ & 22844,0 & 21471,2 & $-6,0$ & 15,8 & 14,4 \\
\hline & - zasoby własne oparte na VAT & 17249,6 & 17738,7 & 2,8 & 11,9 & 11,9 \\
\hline & $\begin{array}{l}\text { - różnica pozostająca do sfinansowania } \\
\text { z zasobów dodatkowych (zasoby włas- } \\
\text { ne oparte na DNB) }\end{array}$ & 102280,9 & 107561,8 & 5,2 & 70,6 & 72,3 \\
\hline 2 & Nadwyżki, salda i dostosowania & 555,5 & & $\times$ & 0,4 & $\times$ \\
\hline 3 & $\begin{array}{l}\text { Dochody pochodzące od osób pracują- } \\
\text { cych w instytucjach i innych organach Unii }\end{array}$ & 1547,4 & 1616,0 & 4,4 & 1,1 & 1,1 \\
\hline 4 & $\begin{array}{l}\text { Dochody z działalności administracyjnej } \\
\text { instytucji }\end{array}$ & 45,1 & 25,1 & $-44,4$ & 0,0 & 0,0 \\
\hline 5 & $\begin{array}{l}\text { Wkłady i zwroty związane z realizacją } \\
\text { porozumień i programów unijnych }\end{array}$ & 110,0 & 130,0 & 18,2 & 0,1 & 0,1 \\
\hline 6 & Odsetki od zaległych płatności i grzywny & 115,0 & 115,0 & 0,0 & 0,1 & 0,1 \\
\hline 7 & Operacje zaciągania i udzielania pożyczek & 6,2 & 2,8 & $\times$ & 0,0 & $\times$ \\
\hline \multirow[t]{2}{*}{8} & Dochody różne & 25,0 & 15,0 & $-40,0$ & 0,0 & 0,0 \\
\hline & Dochody ogółem & 144778,6 & 148675,5 & 2,7 & 100,0 & 100,0 \\
\hline
\end{tabular}

* Z uwzględnieniem budżetu korygującego nr 1 i projektów budżetów korygujących nr 2 i 3.

Źródło: COM(2018) 600 final, s. 2 i 8 ogólnego zestawienia dochodów.

Dominujący udział w wydatkach ogółem budżetu w 2019 r. (wg płatności) będą miały:

- dział 1 - Inteligentny wzrost gospodarczy sprzyjający włączeniu społecznemu 45,4\%. Dział ten obejmuje wydatki na:

- konkurencyjność na rzecz wzrostu gospodarczego i zatrudnienia (dział 1a); w jego ramach proponuje się wydatkowanie kwoty 20,5 mld euro (będzie to o 1,8\% więcej niż w budżecie roku 2018),

- spójność gospodarczą, społeczną i terytorialną (dział 1b); w jego ramach proponuje się wydatkowanie kwoty 47,1 mld euro (będzie to o $1,1 \%$ więcej niż w budżecie roku 2018), 
- dział 2 - Zrównoważony wzrost gospodarczy: zasoby naturalne - 38,9\% udział w wydatkach. W dziale tym zaplanowano wydatkowanie kwoty 57,8 mld euro, tj. o 3\% więcej niż w 2018 r. W przypadku Europejskiego Funduszu Rolniczego Gwarancji - wydatki związane z rynkiem i płatnościami bezpośrednimi będą wyższe niż w 2018 r. o 0,8\%.

Pozostałe działy budżetu charakteryzować się będą znacznie niższym udziałem w wydatkach budżetu UE:

- dział 3 - Bezpieczeństwo i obywatelstwo - 2,3\% udział w wydatkach; w tym dziale zaplanowano prawie 3,5 mld euro, a więc więcej niż w 2018 r. o 17\%,

- dział 4 - Globalny wymiar Europy - 6,4\% udział w wydatkach; w tym dziale zaplanowano 9,5 mld euro, a więc więcej niż w 2018 r. o 6,8\%,

- dział 5 - Administracja - 6,7\% udział w wydatkach, co odpowiada zaplanowaniu kwoty wynoszącej prawie 10 mld euro, tj. wyższej niż w 2018 r. o 3\%.

Tabela 2. Środki na płatności (PA) w mln euro ceny bieżące

\begin{tabular}{|c|c|c|c|c|c|}
\hline \multirow[b]{2}{*}{ Wyszczególnienie } & \multirow{2}{*}{$\begin{array}{l}\text { Budżet } \\
\text { 2018* }\end{array}$} & \multirow{2}{*}{$\begin{array}{l}\text { Budżet } \\
2019\end{array}$} & \multirow{2}{*}{$\begin{array}{c}\text { zmiana } \\
\text { w pkt. proc. }\end{array}$} & \multicolumn{2}{|c|}{ struktura wydatków } \\
\hline & & & & $\begin{array}{l}2018 \text { r. } \\
\text { w \% }\end{array}$ & $\begin{array}{l}2019 \text { r. } \\
\text { w \% }\end{array}$ \\
\hline $\begin{array}{l}\text { 1. Inteligentny wzrost gospodarczy sprzyja- } \\
\text { jący włączeniu społecznemu }\end{array}$ & 66624,5 & 67517,9 & 1,3 & 46,0 & 45,4 \\
\hline $\begin{array}{l}\text { 1a - Konkurencyjność na rzecz wzrostu } \\
\text { gospodarczego i zatrudnienia }\end{array}$ & 20097,2 & 20467,2 & 1,8 & 13,9 & 13,8 \\
\hline $\begin{array}{l}\text { 1b - Spójność gospodarcza, społeczna } \\
\text { i terytorialna }\end{array}$ & 46527,3 & 47050,8 & 1,1 & 32,1 & 31,6 \\
\hline $\begin{array}{l}\text { 2. Zrównoważony wzrost gospodarczy: } \\
\text { zasoby naturalne }\end{array}$ & 56083,8 & 57790,4 & 3,0 & 38,7 & 38,9 \\
\hline $\begin{array}{l}\text { w tym: Europejski Fundusz Rolniczy } \\
\text { Gwarancji (EFRG) - wydatki związane } \\
\text { z rynkiem i płatności bezpośrednie }\end{array}$ & 43188,7 & 43537,9 & 0,8 & 29,8 & 29,3 \\
\hline 3. Bezpieczeństwo i obywatelstwo & 2980,7 & 3486,4 & 17,0 & 2,1 & 2,3 \\
\hline 4. Globalny wymiar Europy & 8906,1 & 9508,4 & 6,8 & 6,2 & 6,4 \\
\hline 5. Administracja & 9666,3 & 9960,9 & 3,0 & 6,7 & 6,7 \\
\hline w tym: wydatki administracyjne instytucji & 7580,7 & 7759,3 & 2,4 & 5,2 & 5,2 \\
\hline 6. Rezerwa ujemna & $-70,4$ & 0,0 & & 0,0 & 0,0 \\
\hline Wydatki ogółem poz. 1-6 & 144261,4 & 148264,0 & 2,8 & 99,6 & 99,7 \\
\hline Inne specjalne instrumenty & 517,2 & 411,5 & $-20,4$ & 0,4 & 0,3 \\
\hline Suma całkowita & 144778,6 & 148675,5 & 2,7 & 100,0 & 100,0 \\
\hline Margines & 10982,0 & 19344,7 & $176,1 \%$ & & \\
\hline Środki jako \% DNB & $0,92 \%$ & $0,90 \%$ & & & \\
\hline
\end{tabular}

* Z uwzględnieniem budżetu korygującego nr 1 i projektów budżetów korygujących nr 2 i 3.

Źródło: $\operatorname{COM(2018)600~final,~s.~7-9.~}$

Jednocześnie zmniejszą się wydatki w ramach innych specjalnych instrumentów (o 20,4\%) i wyniosą one 0,4 mld euro.

Większy będzie także dostępny margines środków, który zaplanowano na kwotę 19,3 mld euro, wobec prawie 11 mld euro w 2018 r.

Szczegółowa analiza planowanych wydatków (wg płatności) wskazuje, że: 
- W dziale 1a - Konkurencyjność na rzecz wzrostu i zatrudnienia, dotyczącym finansowania polityk przyczyniających się do tworzenia zrównoważonej gospodarki o wysokim poziomie zatrudnienia, produktywności i spójności społecznej oraz łączącym wiele głównych inicjatyw strategii „Europa 2020”, planowane wydatki w porównaniu z 2018 r. zwiększą się o prawie 0,4 mld euro.

Wzrost ten spowodowany jest głównie potrzebami związanymi z:

- dużymi projektami infrastrukturalnymi (tj. europejskim systemem nawigacji satelitarnej i europejskim programem monitorowania Ziemi) - wzrost o 0,3 mld euro, tj. o 18,2\%,

- programem „Kształcenie, Szkolenie i Sport” (Erasmus+) ${ }^{14}$ - wzrost o prawie 0,3 mld euro, tj. o $12,5 \%$,

- instrumentem „Łącząc Europę"15 - wzrost o prawie 0,2 mld euro, tj. o 11,7\%,

- Europejskim Programem Rozwoju Przemysłu Obronnego (EDIDP) - na który przewidziano prawie 0,15 mld euro,

- wydatkami agencji zdecentralizowanych - wzrost o 0,1 mld euro, tj. o 27,9\%,

- wydatkami na wspólne ramy strategiczne (WRS) - badania i rozwój - wzrost o 0,1 mld euro, tj. o $0,8 \%$,

- wydatkami na Europejski Korpus Solidarności (ESC) - wzrost o 0,05 mld euro, tj. o $65,1 \%$.

Jednocześnie w odniesieniu do Europejskiego Funduszu na rzecz Inwestycji Strategicznych nastąpi spadek wydatków na kwotę prawie 0,7 mld euro, tj. o 35,9\%. Poza tym istotne zmniejszenie wydatków w porównaniu z 2018 r. dotyczyć będzie także projektów $\mathrm{w}$ dziedzinie energetyki wspomagających naprawę gospodarczą (o 0,15 mld euro, tj. o $71 \%$ ).

- W dziale $1 \mathrm{~b}$ - Spójność gospodarcza, społeczna i terytorialna wydatki zwiększą się o 0,5 mld euro w porównaniu z 2018 r.

Wzrost ten wynika głównie ze zwiększenia płatności na konwergencję regionalną dla regionów słabiej rozwiniętych (o 0,65 mld euro, tj. o 2,8\%), na regiony w okresie przejściowym (o prawie 0,3 mld euro, tj. o 8,2\%), na instrument „Łącząc Europę" - wkład Funduszu Spójności (wzrost o 0,2 mld euro, tj. o 36,1\%).

Jednocześnie płatności dla Funduszu Spójności spadną o 0,75 mld euro, tj. o 8,9\%.

14 Obejmuje on programy sektorowe odpowiadające poszczególnym sektorom kształcenia i szkolenia, tj. edukację, szkolenia młodzieży i sportu oraz wymiany studentów.

15 Program ten wspiera realizację projektów mających na celu rozwój, budowę lub modernizację nowej i istniejącej infrastruktury w dziedzinie transportu, energetyki i telekomunikacji [CEF - Energy, CEF - Transport (stanowiący największą część programu), CEF - Information and Communications Technology (ICT)]; przyczynia się do osiągnięcia inteligentnego i zrównoważonego wzrostu sprzyjającego włączeniu społecznemu poprzez tworzenie nowoczesnych i wysoko wydajnych sieci transeuropejskich. 
- W dziale 2 - Zrównoważony wzrost gospodarczy: zasoby naturalne wydatki wzrosną o 1,7 mld euro, tj. o 3\% w porównaniu z rokiem 2018.

Z ogólnej puli środków w tym dziale na realizację Europejskiego Funduszu Rolniczego Gwarancji (EFRG) - dopłaty bezpośrednie i działania rynkowe - zostanie przeznaczona kwota 43,5 mld euro, tj. wyższa o $0,8 \%$ (0,3 mld euro) w porównaniu z rokiem 2018.

Na Europejski Fundusz Rolny na rzecz Rozwoju Obszarów Wiejskich (EFRROW) przewiduje się kwotę 13,1 mld euro, tj. większą o 10,8\% (1,3 mld euro).

Wydatki Europejskiego Funduszu Morskiego i Rybackiego (EFMR), umowy w sprawie zrównoważonych połowów (SFPA) oraz składki na regionalne organizacje ds. zarządzania rybołówstwem (RFMO) i inne organizacje międzynarodowe mają wynieść 0,7 mld euro, tj. wzrosną o blisko $60 \mathrm{mln}$ euro (9,2\%).

Wydatki na program działań na rzecz środowiska i klimatu (LIFE+) ukształtują się na poziomie $0,3 \mathrm{mld}$ euro (wzrost o 25,5 mln euro, tj. o 8,1\%).

- W dziale 3 - Bezpieczeństwo $i$ obywatelstwo wydatki wzrosną o 0,5 mld euro, tj. o 17\% w porównaniu z rokiem 2018.

Wzrost środków dotyczy przede wszystkim:

- Funduszu Azylu, Migracji i Integracji - o prawie 0,4 mld euro, czyli o 60,3\%,

- Funduszu Bezpieczeństwa Wewnętrznego - o blisko 0,2 mld euro, czyli o $37,9 \%$,

- unijnego mechanizmu ochrony ludności, na który zaplanowano 81,7 mln euro, tj. więcej o 0,05 mld euro (o 138,3\%).

Jednocześnie nastąpi zmniejszenie płatności w odniesieniu do instrumentu na rzecz wsparcia w sytuacjach nadzwyczajnych na terenie Unii (o 0,15 mld euro, tj. o 68,5\%). Zmniejszenia dotyczyć będą także projektów pilotażowych i działań przygotowawczych, systemów informatycznych i sprawiedliwości.

- W dziale 4 - Globalny wymiar Europy ${ }^{16}$ wydatki zwiększą się o 0,6 mld euro, tj. 6,8\% w porównaniu $\mathrm{z}$ rokiem 2018.

Większość, bo aż 70\% wydatków tego działu, stanowią trzy główne programy finansowania działań zewnętrznych (wsparcie finansowe krajów trzecich): Instrument Pomocy Przedakcesyjnej (IPA II), Europejski Instrument Sąsiedztwa (ENI) oraz Instrument Finansowania Współpracy na rzecz Rozwoju (DCI), natomiast pomoc humanitarna - 16,8\% wydatków działu. Finansowanie najważniejszych działań zaplanowanych na 2019 r. obejmuje:

16 Dział ten obejmuje również Instrument na rzecz Przyczyniania się do Stabilności i Pokoju (IcSP). W dziale tym uwzględnia się również środki na pomoc humanitarną, wspólną politykę zagraniczną i bezpieczeństwa (CFSP) oraz pomoc makrofinansową dla państw trzecich i fundusz gwarancyjny dla działań zewnętrznych. 
- IPA II - 1,8 mld euro (wzrost o 0,3 mld euro, czyli o $23,8 \%$ ),

- DCI - 2,8 mld euro (wzrost o 61,7 mln euro, czyli o 2,3\%),

- ENI - 2,1 mld euro (spadek o 0,2 mld euro, czyli o 9,6\%),

- Instrument Partnerstwa - 99,6 mln euro (spadek o 1,1 mln euro, czyli o 1,1\%),

- IcSP - 321,3 mln euro (spadek o prawie 4 mln euro, czyli o 1,2\%),

- pomoc humanitarna - 1,6 mld euro (wzrost o 0,5 mld euro, czyli o 46,4\%).

W projekcie budżetu mniejsze w stosunku do 2018 r. będą środki na płatności w odniesieniu m.in. do: Funduszu Gwarancyjnego dla działań zewnętrznych (GF) (o 89,6 mln euro, tj. o 65\%), Europejskiego Instrumentu na rzecz Wspierania Demokracji i Praw Człowieka (EIDHR) (o $10 \mathrm{mln}$ euro, tj. o 5,9\%), projektów pilotażowych i działań przygotowawczych (o 9,4 mln euro, tj. o 65,6\%).

- W dziale 5 - Administracja wydatki zwiększą się prawie o 0,3 mld euro, tj. o $3 \% \mathrm{w}$ porównaniu z rokiem 2018.

Na Komisję przypada 36,5\% całkowitych wydatków działu 5, a na pozostałe instytucje $-41,4 \%$, na emerytury zaś przypada $20,2 \%$, na szkoły europejskie $1,9 \%$.

Wydatki administracyjne Komisji będą wyższe o $2 \%$ w porównaniu z rokiem 2018, a wydatki innych instytucji ujmowanych łącznie będą większe o 2,6\%. W najwyższym stopniu - bo aż o 6,2\% wzrosną wydatki na emerytury pracownicze. Wydatki na szkoły europejskie będą niższe o $0,4 \%$.

Jeśli chodzi o inne instytucje, to wzrost wydatków jest zróżnicowany od 0,8\% w odniesieniu do Europejskiego Trybunału Obrachunkowego do 16\% w przypadku Europejskiego Inspektora Ochrony Danych Osobowych. Tak wysoki wzrost (z odpowiadającą mu kwotą - 2,3 mln euro) wynika prawie całkowicie z nowych obowiązków Sekretariatu Europejskiej Rady Ochrony Danych oraz dodatkowych potrzeb związanych z nowymi przepisami w zakresie ochrony danych $w$ instytucjach UE, a także monitorowania i zapewnienia przestrzegania przepisów o ochronie danych przez agencje dawnego trzeciego filara.

Jednocześnie Komisja przypomniała, że w 2018 r. możliwa była ocena realizacji celu określonego w 2013 r., który zakładał ograniczenie ogólnej liczby personelu $\mathrm{w}$ agencjach o $5 \%{ }^{17}$. $\mathrm{Z}$ oceny tej wynikało, że redukcja personelu $\mathrm{w}$ większości agencji została zasadniczo przeprowadzona zgodnie z planem, na jej ostateczne wyniki duży wpływ miały jednak wyzwania związane z migracją i bezpieczeństwem, jakie pojawily się w ostatnich latach. Skutki tych wyzwań są nadal odczuwalne i będą wymagały uwzględnienia również w 2019 r. Należy też pamiętać, że w projekcie budżetu na 2019 r. przewidziano rezerwę na ustanowienie Europejskiego Urzędu ds. Pracy oraz Prokuratury Europejskiej, jak również zaproponowano wzmocnienie agencji zajmujących się kwestiami migracji i bezpieczeństwa oraz organów nadzoru finansowego - $\mathrm{z}$ uwagi na ich nowe zadania.

17 Swój cel w zakresie ograniczenia zatrudnienia o 5\% Komisja zrealizowała wcześniej. 
Przy opracowywaniu projektu budżetu na 2019 r. Komisja zachęciła wszystkie instytucje i organy UE do tego, by w trakcie opracowywania swoich preliminarzy zastosowały rygorystyczne podejście w odniesieniu do liczby pracowników i wydatków administracyjnych. Niemniej Komisja stwierdziła, że ma świadomość, iż zamrożenie kosztów w ujęciu nominalnym przez osiem lat z rządu staje się coraz trudniejsze.

Tabela 3. Wydatki administracyjne (kwoty w mln euro, w cenach bieżących)

\begin{tabular}{|c|c|c|c|c|c|}
\hline & \multirow[b]{2}{*}{$\begin{array}{c}\text { Budżet } \\
2018\end{array}$} & \multirow{2}{*}{$\begin{array}{c}\text { Projekt } \\
\text { budżetu } \\
\text { UE na rok } \\
2019\end{array}$} & \multirow[b]{2}{*}{$\begin{array}{c}\text { Udział } \\
\text { w \% }\end{array}$} & \multicolumn{2}{|c|}{ Różnica } \\
\hline & & & & $\begin{array}{l}2019- \\
2018\end{array}$ & $\begin{array}{c}2019 / \\
2018 \\
\text { w \% }\end{array}$ \\
\hline Emerytury i szkoły europejskie & 2085,6 & 2201,6 & 22,1 & 116,0 & 5,6 \\
\hline Emerytury & 1892,8 & 2009,5 & 20,2 & 116,7 & 6,2 \\
\hline Emerytury pracownicze & 1867,2 & 1983,0 & 19,9 & 115,9 & 6,2 \\
\hline Emerytury dla byłych członków & 25,7 & 26,5 & 0,3 & 0,8 & 3,3 \\
\hline Szkoły europejskie & 192,8 & 192,1 & 1,9 & $-0,7$ & $-0,4$ \\
\hline Wydatki administracyjne instytucji & 7579,9 & 7755,3 & 77,9 & 175,4 & 2,3 \\
\hline Komisja Europejska & 3565,5 & 3637,2 & 36,5 & 71,7 & 2,0 \\
\hline Inne instytucje & 4014,4 & 4118,1 & 41,4 & 103,7 & 2,6 \\
\hline Parlament Europejski & 1950,2 & 1998,5 & 20,1 & 48,3 & 2,5 \\
\hline Rada Europejska i Rada UE & 572,9 & 583,0 & 5,9 & 10,1 & 1,8 \\
\hline Europejski Trybunał Sprawiedliwości & 410,0 & 430,0 & 4,3 & 20,0 & 4,9 \\
\hline Europejski Trybunał Obrachunkowy & 146,0 & 147,3 & 1,5 & 1,2 & 0,8 \\
\hline Europejski Komitet Społeczno-Ekonomiczny & 135,6 & 138,8 & 1,4 & 3,1 & 2,3 \\
\hline Komitet Regionów & 96,1 & 98,9 & 1,0 & 2,8 & 2,9 \\
\hline Rzecznik Praw Obywatelskich & 10,6 & 11,3 & 0,1 & 0,7 & 6,4 \\
\hline Europejski Inspektor Ochrony Danych Osobowych & 14,4 & 16,8 & 0,2 & 2,3 & 16,0 \\
\hline Europejska Służba Działań Zewnętrznych & 678,5 & 693,7 & 7,0 & 15,2 & 2,2 \\
\hline Razem & 9665,5 & 9956,9 & 100,0 & 291,4 & 3,0 \\
\hline Limit & 10346,0 & 10786,0 & & & \\
\hline Margines & 362,5 & 575,2 & & & \\
\hline
\end{tabular}

Źródło: COM(2018) 600 final, s. 65.

\section{- Geneza dokumentu UE}

Elementy procedury budżetowej ustala art. 310-316 Traktatu o funkcjonowaniu Unii Europejskiej (TFUE). Głównymi instytucjami UE zaangażowanymi w jego przyjmowanie są: Komisja, Rada i Parlament Europejski.

Roczny budżet UE powinien być zgodny z wieloletnimi ramami finansowymi (ustalanymi na okres co najmniej 5 lat), które mają na celu zapewnienie dokonywania wydatków UE w sposób usystematyzowany i w granicach jej zasobów własnych. Ramy te określają kwoty rocznych pułapów środków na zobowiązania, z podziałem na kategorie wydatków oraz roczny pułap środków na płatności.

Należy wskazać, że z przedłożonym projektem budżetu powiązanych jest wiele dokumentów, w tym:

- komunikat Komisji do Rady i Parlamentu Europejskiego: Dostosowanie techniczne ram finansowych na 2019 r. do zmian DNB (ESA 2010) (art. 6 rozpo- 
rządzenia Rady nr 1311/2013 określającego wieloletnie ramy finansowe na lata 2014-2020), $\operatorname{COM(2018)~} 282$ final,

- wniosek dotyczący decyzji Parlamentu Europejskiego i Rady w sprawie uruchomienia Funduszu Solidarności Unii Europejskiej w celu zapewnienia środków na wypłatę zaliczek w budżecie ogólnym Unii na 2019 r., COM(2018) 281 final,

- wniosek dotyczący decyzji Parlamentu Europejskiego i Rady w sprawie uruchomienia instrumentu elastyczności na sfinansowanie natychmiastowych środków budżetowych służących do rozwiązywania bieżących problemów wynikających z migracji, napływu uchodźców i zagrożeń bezpieczeństwa oraz rozszerzenia programu wspierania reform strukturalnych, COM(2018) 280 final.

\section{- Informacja o stanie prawa obowiązującego w Polsce w materii objętej treścią dokumentu UE}

Przyjęcie budżetu ogólnego UE nie ma wpływu na polskie prawodawstwo (dokument nie wymaga transpozycji do polskiego porządku prawnego). Prawo polskie nie reguluje zasad i procedur uchwalania budżetu UE.

\section{Ocena dokumentu UE}

\section{- Ocena skutków finansowych dokumentu UE}

Ocena projektu budżetu na 2019 r. jest generalnie pozytywna, bo jest to budżet nieco większy niż budżet roku bieżącego, który finansować będzie w zasadzie na dotychczasowym poziomie wydatki działu la - Konkurencyjność na rzecz wzrostu gospodarczego i zatrudnienia i działu 1b - Spójność gospodarcza, społeczna i terytorialna (aczkolwiek kwestionowane mogą być szczegółowe wydatki zaplanowane w tych działach, np. zmniejszenie płatności na konkurencyjność przedsiębiorstw oraz małych i średnich przedsiębiorstw czy wzrost wydatków na regiony w okresie przejściowym i na regiony najbardziej oddalone i słabo zaludnione). Budżet ten zapewni też wzrost wydatków działu 2 - Zrównoważony wzrost gospodarczy: zasoby naturalne, w tym zwłaszcza w odniesieniu do funduszy rolniczych, umożliwi większe płatności związane $\mathrm{z}$ funduszami morskimi i rybackimi oraz z działaniami na rzecz środowiska i klimatu. Poza tym przewiduje on istotne zwiększenie wydatków na bezpieczeństwo i reagowanie na ostatnie wyzwania związane z migracją.

Niemniej powstają obawy, czy zaplanowany poziom płatności będzie wystarczający. Rząd z niepokojem zauważa, że proponowany w projekcie budżetu poziom płatności jest na tym samym poziomie, co płatności w wykonanym budżecie za rok 2013 - co przy stosowanym w WRF rocznym deflatorze inflacyjnym (2\%) oznacza spadek budżetu o 12,6 pkt proc. Ponadto może on nie pozwolić sprostać spodziewanej już w roku 2018 kumulacji płatności w ramach polityki 
spójności oraz zwiększonemu zapotrzebowaniu na płatności na rzecz migracji i innych nowych wyzwań.

Niepokój może także budzić stały wzrost wydatków o charakterze administracyjnym. Są to wydatki ujęte w dziale 5 - Administracja oraz w innych działach, w których przewidziane są wydatki na agencje zdecentralizowane. Środki na płatności w odniesieniu do wydatków administracyjnych sięgają już ok. 7,7\% całkowitych wydatków. W tym kontekście można postawić pytanie dotyczące celowości powoływania ciągle nowych instytucji, które z czasem będą rozrastać się, mnożyć swoje zadania, a efekty ich działalności niekoniecznie będą satysfakcjonujące w odbiorze europejskiego podatnika.

Powstaje też pytanie, dlaczego wydatki np. Parlamentu Europejskiego, Rady Europejskiej i Rady UE, różnych komitetów rosną szybciej niż wydatki tak ważniej instytucji jak Europejski Trybunał Obrachunkowy.

Inne pytanie dotyczyć może tego, czy sprawiedliwe jest przeznaczanie coraz większych środków na emerytury z budżetu unijnego, skoro w wielu państwach UE, nawet tych bogatych, systemy emerytalne stoją przed ogromnymi wyzwaniami dotyczącymi m.in. tego, czy będą w stanie zapewnić wielu obywatelom (w tym dobrze wykształconym i o relatywnie długim stażu pracy) odpowiedni poziom emerytur.

Warto też dodać, że proponowane dalsze zwiększanie środków na zobowiązania (aczkolwiek niewielkie i uzasadnione) generować może w przyszłości potrzebę zwiększenia płatności, a także wzrostu składki do budżetu UE, która może ulec zwiększeniu po wyjściu Wielkiej Brytanii z UE.

Przyjęcie proponowanego projektu budżetu nie spowoduje skutków społecznych i gospodarczych w Polsce. Jeśli chodzi o skutki finansowe, to należy wskazać, że zaplanowana kwota dochodów i środków na płatności (148,7 mld euro) będzie sfinansowana w ramach składki do budżetu ogólnego UE przez wszystkie państwa członkowskie, zgodnie z ich procentowym udziałem w sumie zasobów własnych UE.

Polska wpłaci do budżetu UE środki w kwocie ok. 5 mld euro (stanowiącą ok. 3,4\% udziału we wpłatach wszystkich państw członkowskich z tytułu zasobów własnych ${ }^{18}$ ), tj. kwotę nieco wyższą od obecnie uiszczanej. Największej wpłaty dokonają Niemcy - 30,6 mld euro (20,8\% udział), Francja - 22,7 mld euro (15,4\% udział), Wielka Brytania - 17,6 mld euro (12,0\% udział), Włochy - 17,1 mld euro (11,6\% udział) i Hiszpania - 12,2 mld euro (8,3\% udział $)^{19}$.

Do tej pory Polska otrzymywała więcej środków z budżetu unijnego niż do niego wpłacała. Przykładowo w 2017 r. Polska otrzymała z tego budżetu 11,2 mld

Zob. t. I, Dochody ogótem, tab. 7, kol. 11, s. 7 i n.

19 Zob. ostatnia kolumna tabeli 1.A, $\operatorname{COM}(2018) 600$ final. Przytaczamy tu dane z kolumny 11 i 12, a nie z kolumn 9 i 10, ponieważ ta ostatnia kolumna uwzględnia wszystkie zasoby własne (tj. także tradycyjne zasoby własne netto) w kwocie 143 570,8 mln euro. 
euro, przy składce na poziomie ok. 3,6 mld euro, co dawało dodatnią pozycję netto w wysokości ok. 7,6 mld euro.

W roku 2019, wobec osiągnięcia poziomu 95\% wydatkowania środków z okresu programowania 2007-2013 w ramach polityki spójności (fundusze strukturalne oraz Fundusz Spójności), płatności pośrednie dla Polski z tego tytułu będą ograniczone. Pozostałe 5\% środków będzie wypłacone po sprawdzeniu przez Komisję Europejską, czy nie pojawiają się błędy w rozliczeniach. Zgodnie z informacjami przekazanymi przez Komisję większość płatności z tytułu wymienionych 5\% nastąpi najprawdopodobniej w 2018 r., a mniejsza część z tychże $5 \%$ zostanie przekazana w $2019 \mathrm{r}$.

\section{- Ocena zgodności dokumentu UE z zasadą pomocniczości}

Dokument nie podlega ocenie co do zgodności z zasadą pomocniczości w trybie protokołu nr 2.

\section{- Ustosunkowanie się do projektu stanowiska RP}

Przedstawiony przez Radę Ministrów projekt stanowiska RP nie budzi zastrzeżeń. W pełni zaakceptować należy zapowiedź rządu, że jego stanowisko w trakcie prac nad budżetem UE na rok 2019 będzie ukierunkowane na zapewnienie niezbędnych środków finansowych na spłacenie zobowiązań wcześniej zaciągniętych przez państwa członkowskie w imieniu budżetu UE (w szczególności dotyczy to polityki spójności oraz rozwoju obszarów wiejskich, które są bardzo istotnymi instrumentami inwestycyjnymi w UE).

Pozytywnie należy ocenić konsekwentne stanowisko rządu odnośnie do tego, że zasadne jest jasne uregulowanie $\mathrm{w}$ przyszłości płatności od instrumentów specjalnych ( $\mathrm{tj}$. ujmowania ich poza WRF) oraz stanowisko w odniesieniu do kwestii kryzysu migracyjnego i wydatków administracyjnych. Zgodzić się także można $\mathrm{z}$ tym, że z powodów prawnych i proceduralnych elementy projektu budżetu UE na rok 2019 powiązane z niezakończonymi procesami legislacyjnymi (m.in. Europejski Urząd ds. Pracy, Unijny Mechanizm Ochrony Ludności, Europejski Program Rozwoju Przemysłu Obronnego, Europejski Korpus Solidarności, Instrument Pomocy dla Uchodźców w Turcji, Program Wspierania Reform Strukturalnych 2.0) powinny zostać usunięte z projektu lub co najmniej odpowiednio zaznaczone (np. pozostawione w rezerwach budżetowych).

\section{Opinia prawna}

\section{Podstawa prawna dokumentu UE}

Podstawą prawną przyjęcia projektu budżetu ogólnego UE jest art. 314 TFUE. W przepisie tym ustanowiona została specjalna procedura ustawodawcza, według której Parlament Europejski i Rada ustanawiają roczny budżet UE. Zgod- 
nie $\mathrm{z}$ tą procedurą projekt budżetu, obejmujący prognozę dochodów i wydatków, przedstawiany jest Parlamentowi Europejskiemu i Radzie nie później niż 1 września roku poprzedzającego rok, w którym budżet ma być wykonywany. Rada obowiązana jest przyjąć stanowisko w sprawie projektu budżetu i przekazać je Parlamentowi Europejskiemu nie później niż 1 października tego roku. W ramach tej procedury, w przypadku zgłoszenia przez Parlament Europejski poprawek do projektu, może zostać powołany komitet pojednawczy, składający się z przedstawicieli Parlamentu i Rady. Podstawa prawna przyjęcia budżetu przewiduje procedurę ustawodawczą. Opiniowany projekt dotyczy działań prawodawczych w obszarze należącym do kompetencji UE, które wykonywane są wspólnie przez Parlament Europejski i Radę. Przedłożony projekt jest projektem aktu ustawodawczego. Wybór procedury i zastosowanego środka nie nasuwa - w świetle brzmienia art. 314 TFUE - wątpliwości. Projekt nie podlega ocenie parlamentów narodowych pod względem zgodności z zasadą pomocniczości w trybie określonym w protokole nr 2, ponieważ państwa członkowskie Unii Europejskiej nie dysponują kompetencją do stanowienia budżetu Unii Europejskiej.

\section{Skutki prawne}

Przyjęcie budżetu ogólnego UE nie będzie się wiązało z koniecznością dokonania zmian implementacyjnych w ustawodawstwie polskim. Projekt budżetu nie budzi wątpliwości legislacyjnych.

\section{Kwestie proceduralne}

\section{- Tryb stanowienia budżetu}

Projekt budżetu, zgodnie ze wskazaną podstawą prawną, powinien być przyjęty w specjalnej procedurze ustawodawczej. Rada stanowi większością kwalifikowaną. Projekt został przyjęty przez Komisję 21 czerwca 2018 r. Tego samego dnia został przekazany Parlamentowi Europejskiemu i Radzie. Obecnie stanowi przedmiot prac obu tych instytucji.

\section{- Działania Komisji ds. Unii Europejskiej}

Rada Ministrów przekazała Sejmowi projekt stanowiska RP na temat projektu budżetu 6 lipca 2018 r., zachowując tym samym 14-dniowy termin, który został określony w art. 7 ust. 1 ustawy o współpracy Rady Ministrów z Sejmem i Senatem w sprawach związanych z członkostwem RP w Unii Europejskiej. Zgodnie $\mathrm{z}$ art. 7 ust. 4 ustawy Komisja ds. UE może wyrazić opinię o projekcie aktu UE w terminie 49 dni od dnia przekazania Sejmowi tego aktu. Termin na wyrażenie opinii przez Komisję ds. UE upływa 12 sierpnia 2018 r. 


\section{Konkluzje}

Ocena projektu budżetu na 2019 r. jest generalnie pozytywna, aczkolwiek nie pozbawiona elementów krytycznych, w tym zwłaszcza w odniesieniu do wydatków administracyjnych i poziomu środków na płatności.

Przedstawiony przez Radę Ministrów projekt stanowiska RP nie budzi zastrzeżeń. 